\title{
Performing Counter-Hegemonic Common(s) Senses: Rearticulating Democracy, Community and Forests in Puerto Rico
}

\section{Gustavo A. García López, Irina Velicu \& Giacomo D’Alisa}

To cite this article: Gustavo A. García López, Irina Velicu \& Giacomo D’Alisa (2017): Performing Counter-Hegemonic Common(s) Senses: Rearticulating Democracy, Community and Forests in Puerto Rico, Capitalism Nature Socialism, DOI: 10.1080/10455752.2017.1321026

To link to this article: http://dx.doi.org/10.1080/10455752.2017.1321026

Published online: 02 May 2017.

Submit your article to this journal $\sqsubset$

a

View related articles $\llbracket$

View Crossmark data ¿ 


\title{
Performing Counter-Hegemonic Common(s) Senses: Rearticulating Democracy, Community and Forests in Puerto Rico
}

\author{
Gustavo A. García López ${ }^{\mathrm{a}}$, Irina Velicu ${ }^{\mathrm{b}}$ and Giacomo D'Alisa ${ }^{\mathrm{c}}$ \\ ${ }^{a}$ Escuela Graduada de Planificación, Universidad de Puerto Rico - Río Piedras, San Juan, Puerto

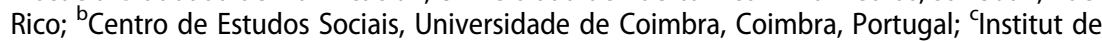 \\ Ciència i Tecnologia Ambientals, Universitat Autònoma de Barcelona, Bellaterra, Spain
}

\begin{abstract}
Political ecologists have developed scathing analyses of capitalism's tendency for enclosure and dispossession of the commons. In this context commons are analyzed as a force to resist neo-liberalism, a main site of conflict over dispossession, and a source of alternatives to capitalism. In this paper we elaborate a view of the commons as the material and symbolic terrain where performative re-articulation of common(s) senses can potentially enact counter-hegemonic socio-ecological configurations. Expressly drawing on the concepts of hegemon, "common-senses" (inspired by Antonio Gramsci) and "performativity" (developed by Judith Butler), we argue that counterhegemony is performed through everyday practices that rearticulate existing common senses about commons. Commoning is a set of processes/relations enacted to challenge capitalist hegemony and build more just/sustainable societies insofar as it transforms and rearranges common senses in/through praxis. The paper draws on the experience of an anti-mining movement of Casa Pueblo in Puerto Rico, which for the last 35+ years has been developing a project self-described as autogestion. The discussion pays special attention to Casa Pueblo's praxis and discourses to investigate how they rearticulate common senses with regard to nature, community and democracy, as well as their implications for counter-hegemonic politics.
\end{abstract}

ARTICLE HISTORY Received 1 May 2016; Accepted 1 March 2017

KEYWORDS Commons; commoning; political ecology; counter-hegemony; common senses; performativity; Casa Pueblo

\section{Introduction}

Political ecology scholars have increasingly focused on the concept of the commons to understand anti-capitalist struggles. Most of this work centers around "enclosure" of common resources for capitalist accumulation as a recurrent process (De Angelis 2001) or "accumulation by dispossession" (Harvey 2003). Political ecologists have noted the interrelation between 
enclosures/dispossessions constitutive of capitalist hegemony (e.g. Brand and Görg 2013; De Angelis 2001; Goldman 1993; Heynen and Robbins 2005; Johnston 2003; Karriem 2013), and struggles that emerge to defend and reproduce commons (Caggiano and De Rosa 2015; Compost and Navarro 2014; D’Alisa, Forno, and Maurano 2015; De Angelis 2012; Turner and Brownhill 2004, 2010; Varvarousis and Kallis 2017). These struggles can produce an "uncivil" society that challenges hegemonic ideas, and experiment with new ones (Armiero and D'Alisa 2012).

Political ecologists are increasingly looking at commons as a keyword associated with these movements and their collective practices: communal management of forests and fisheries, occupied social centers and housing cooperatives (see, e.g. Bollier and Helfrich 2015). Commons are proposed as the "seeds" of an "alternative form of production in the make" (Caffentzis and Federici 2014, i95). McCarthy $(2005,16)$ proposed that 'defenses of 'commons' or calls for new ones are ... truly counterhegemonic projects, reminders that ... alternative social relations are entirely thinkable." To further elaborate this thesis we intersect concepts developed by Antonio Gramsci and Judith Butler to draw two insights: first, the key role of "common senses" as a constitutive dimension of hegemonic conditions; and second, their performativity - how these common senses are continually reproduced and/or rearticulated as well as challenged through everyday practices and discourses. Because hegemony is performative (constituted through daily repetitive practices and discourses), we argue that commoning - as a habitual performance in the everyday - can be a key to counter-hegemony, generating new common senses which are materially and symbolically articulated around commons, that is, what we mean by common(s) senses. To build this argument we analyze the case of Casa Pueblo in Puerto Rico which began more than 30 years ago as an anti-mining struggle evolving into a commoning experiment. We maintain this case demonstrates the potentiality of commoning as performance to challenge hegemonic common senses about democracy, community and forests.

\section{Commoning as Performing (Counter) Hegemony}

Social transformation occurs not merely by rallying mass numbers in favor of a cause, but precisely through the ways in which daily social relations are rearticulated.

- Judith Butler $(2000,14)$

... to create one's personality means to acquire consciousness of [social relations] and to modify one's own personality means to modify the ensemble of these relations.

- Antonio Gramsci (1971, 352)

Hegemony has been proposed as an indispensable concept for understanding and building anti-capitalist struggles today (Karriem 2013). Political 
ecologists have paid increasing attention to this and other Gramscian concepts (e.g. Ekers et al. 2013). This section explores the resonances between Gramsci and Butler in order to propose new theoretical directions for the analysis of commoning as a performativity of counter-hegemonic common(s) senses. ${ }^{1}$

Hegemony - rule by consent rather than force - is intrinsically dependent on the formation, sedimentation and re-articulation of common senses (D'Alisa and Kallis 2016), defined as "uncritical and largely unconscious way(s) of perceiving and understanding the world that has become 'common' in any given epoch" (Gramsci 1971, 322). Common senses emerge through existing practices and relations between people and with their environment (Gramsci in Karriem 2013). "New" common senses emerge not as rejection of existing ones but by "renovating and making 'critical' an already existing activity" (Gramsci 1971, 331).

As Karriem (2013, 144) notes, since "hegemony is produced through spatial practices that normalize ruling ideas [i.e. common senses] in everyday life," so too building counter-hegemony requires organized practices that repoliticize (make collective) dominant ideas. Transforming common senses requires performing new socio-ecological (power) relations in the everyday life of routinized sociality. This performative approach to hegemony sees ideology not as false consciousness but as enactment of concepts, languages and imaginaries (Ekers 2013). The different commons senses that inhabit us are very often in contradiction with one another. An effective hegemony makes sense of incongruities among various discourses, prioritizing some sensi comuni (Italian for "plural") to the detriment of others. The continuous emergence of capitalist contradictions implies hegemony is constantly rearticulating the order of common senses, a process that is never complete: there is always an "in-betweenness," an openness to different possibilities that can serve as a new beginning (De Angelis 2007). The challenge for Gramsci is that "alternative or dormant common senses can ... be combined to build a counter-hegemonic narrative" (D’Alisa and Kallis 2016, 213).

Butler $(2000,14)$ has stressed the "continuing political promise of the Gramscian notion of hegemony" for the project of radical democracy. For her, hegemony implies a rethinking of capitalist structures to consider "the ways in which power operates to form our everyday understanding of social relations and to orchestrate the ways in which we consent to (and reproduce) those tacit and covert relations" (Butler 1997). Power is remade in everyday life through "performativity": "repetition, convergence and rearticulation ... not immediately coopted by social formations” (Butler 1997, 2000).

\footnotetext{
${ }^{1}$ Some could consider a dialogue between Gramsci and Butler untenable, yet we avow the search in the blurred space of these approaches. There is an increasing number of works comparing Gramsci and Foucault (a main inspiration for Butler) which are relevant for this proposal (see, e.g. Kreps 2015; Sevilla-Buitrago 2017).
} 
Habituated, normalized acts are also (re)producing identitarian subjects; yet the performative character of power also puts it at risk because of "anomalous and subversive practices" that deviate from the norm, that is, that may be done differently (Butler 2000, 14; Butler 1997). Thus, Butler $(2000,14)$ concludes that "performativity is not far from the theory of hegemony ... both emphasize the way ... new social possibilities emerge" through social actions.

Since what we (humans) are is "always a doing" (Butler 1999, 33), the task for a counter-hegemonic politics "is not whether to repeat, but how" to do so in a way that questions, disturbs and displaces "the very norms that enable repetition itself" and opens them to resignification (Butler 1999, 148). Performing differently means "taking charge of one's own becoming as a political subject ... a difficult process of reimagining and a performed transformation in the everyday sites of power relations" (Velicu and Kaika forthcoming, 9). Butler (2015) has recently argued that dispossession is a major driving force of performative reenactments of radical solidarity, especially through the bodily politics of occupation and assembly.

However, there is still little work addressing struggles for commoning through the lens of performativity as a key to counter-hegemony. Some indications may be offered in the "commoning" scholarship, which sees commons as dialectical webs of everyday practices through which people care for and (re)produce their ecological and social sustenance (Bollier and Helfrich 2015; Bresnihan 2016; D’Alisa 2013; Federici 2012; Linebaugh 2008). In this view commoning processes are "the production of ourselves as a common subject" (Federici 2012, 145). As De Angelis $(2007,239)$ puts it, "capital generates itself through enclosures, while subjects in struggle generate themselves through commons. Hence, 'revolution' is not struggling for commons, but through commons...." Ecofeminist scholarship also provides important insights on the gendered and racialized commons' enclosures, showing that ecological issues are social reproductive issues, and challenging the dualism of nature (white/male) culture-reason (Di Chiro 2008; Federici 2012; Tola 2015). Movements often struggle against extractive projects and in defense of their "collective and life-centered project of subsistence commoning" (Turner and Brownhill 2004). Gibson-Graham (2006), Mackenzie (2010), Nightingale (2013) and Singh (2013), partly drawing on Butler, have also suggested how collective subjectivities and "new senses of self" disrupting the "capitalocentric imaginary" emerge in commoning processes. This reflects "a practice of life that takes care of interests in common" while disrupting the hegemonic consensus that invisibilizes and wages war on other worlds (De la Cadena 2015).

Commons projects are not inherently counter-hegemonic. They have also been deployed as part of the neoliberal project in ways that do not question hegemonic ecological politics, leaving aside power, injustice and the structural conditions of capitalism and liberal democracy (De Angelis 2013; Caffentzis 
and Federici 2014). Thus, there is a need to analyze specific commoning processes (Chatterton, Featherstone, and Routledge 2013) - their particularities, contradictions, limitations - and how they perform new common(s) sense. With this in mind, in the following section we discuss the case of Casa Pueblo. We first establish the context of Puerto Rico's environmental colonialism and then analyze how Casa Pueblo has carried out a performative rearticulation of common senses. We draw on material gathered from published research and reflections from their leaders (mainly from founders Alexis Massol-González and Tinti Deyá and their son, Arturo Massol-Deyá (see Massol-González et al. 2006, 2008), other published and unpublished research (e.g. Martínez-Reyes 2009), published press reports, documentaries, ${ }^{2}$ and this article's leading author's personal observations based on over a decade of interaction with Casa Pueblo members in different roles (as student, professor, activist, government representative) and various settings (visits, protests, meetings, collaborations in the organization's projects and personal conversations).

\section{Puerto Rico's Environmental Colonialism and Casa Pueblo's Emerging Commoning as a Counter-Hegemonic Movement}

Puerto Rico is the oldest remaining colony of in the world, ${ }^{3}$ a clear example of the dispossessions associated with capitalism's "environmental colonialism" (Concepción 1995). Spain's implementation of a plantation economy on the island led to 90 percent of it being deforested by the end of the $19^{\text {th }}$ century (Massol-González et al. 2006). The U.S. occupation force coupled the sugar empire developed by the Spanish with military bases across the island. Forest areas were used for high-value timber species and implementation of the U.S.' "fortress conservation" model of protected areas. At the end of the 1940s (and until the 1970s) the U.S. began promoting a large-scale industrialization as Operation Bootstrap. The need for raw materials to feed the American post-war economic "boom" led to a proliferation of mineral exploration permits by U.S. companies in Puerto Rico. A pit mine for copper and gold was proposed on 14,000 hectares of the island's Cordillera Central (Colón-Rivera, Córdova-Iturregui, and Córdova-Iturregui 2014). The Cordillera Central is the central mountainous region of Puerto Rico with a high proportion of forest and agriculture lands. It is the birth point of some of the country's most important rivers and strong cultural and material attachment to the territory. It was also the stronghold of the two attempted independence revolutions in the country's history (in 1868 and 1950).

\footnotetext{
${ }^{2}$ See https://www.youtube.com/watch?v=YGy15DoEHFQ.

${ }^{3}$ Puerto Rico was a colony of Spain for 400 years and a US colony since 1898.
} 
In this context a strong movement against the mining project quickly emerged in the 1960s, led by leftist nationalists. Initially it partly reproduced the developmentalist common sense of the time. With the slogan "Puerto Rican mines or no mines," the leading groups opposed mining conditionally, since they saw these resources as national patrimony to be used by the future republic (Concepción 1995). However, under the influence of ecological scientists and radical environmentalists, the movement slowly began incorporating concerns about the project's environmental impacts, associated with a strong cultural-ecological attachment to the landscape (ColónRivera, Córdova-Iturregui, and Córdova-Iturregui 2014; Concepción 1995). The Socialist League was the only organization that rejected mining entirely even in a future independent republic, claiming the ecological impacts would "exterminate" the country (Anazagasty-Rodríguez 2015).

Amidst the growing chorus of voices against mining the governor decided to veto it in 1968. The project was proposed again by the next two governors and again defeated by opposition movements. It reappeared once more in 1980, for an even-larger area of 36,000 hectares covering six municipalities - as Plan 2020 - of industrialization, infrastructure and military bases designed by the U.S. (Cela 2014). That year the entity Taller de Arte $y$ Cultura (Workshop of Art and Culture) - later renamed Casa Pueblo - was established by local residents in the mountain town of Adjuntas to renew the anti-mining struggle. The founders were disciples of J. A. Corretjer, the leader of the Socialist League.

\section{Casa Pueblo's Performative Counter-Hegemony: Rearticulating Common(s) Senses on Democracy, Community and Nature}

Casa Pueblo leaders always begin their story reminiscing how only one person came to the first action they organized in Adjuntas' plaza to protest the mining project. This led them to rethink their strategy. At the Patria Adentro ("Homeland Inside") festival and other similar events they mobilized cultural ties to the territory through traditional music, dance, food, kite flying, reforestation activities and display of large banners showing the damage mining would cause to the landscape (Deyá in Hopgood-Dávila 2015). They urged attendees to imagine where poets and troubadours could get their inspiration from if the mountains disappeared (Martínez-Reyes 2009).

Later, in 1992, when a new government revived the mining proposal, Casa Pueblo was able to mobilize thousands of people against it. In 1995 it succeeded in stopping the project with the signing of a reformed mining law which prohibited open pit mining. However, aware of the dormant danger of enclosure, they proposed to move beyond conventional struggles against mining to the construction of practical alternatives (Massol-González in Hopgood-Dávila 2015): from building "dikes against neoliberal enclosures" 
(cf. Caffentzis and Federici 2014) to enacting different socio-ecological relations of power (Velicu and Kaika 2015).

This new politics was built on the principle of autogestion to break "the bonds of dependency and political manipulation" and develop independent voice and initiatives (Massol-González et al. 2006, 7). ${ }^{4}$ Based on this emerging "common(s) sense," Casa Pueblo proposed that the government designate the area as a protected forest, and that it participate alongside the government as equals in making decisions about the forest's conservation and management. In 1996 their proposed forest, Bosque del Pueblo (People's Forest), became Puerto Rico's first forest designated for legal protection with the first ever co-management agreement for a protected area. In other words, protecting the commons as counter-hegemonic - collective, political, open to ongoing communal re-negotiation rather than merely economic/private ownership has been done by performing a re-articulation of a common sense of democracy beyond representation and through direct participation.

This territorial occupation provided the material basis for the commoning initiative that has been sustained and evolved over the last $30+$ years. From forest co-management Casa Pueblo has expanded its counter-hegemonic performative activities into many different fields that have challenged capitalist forms of monetary and private economic operation: an educational project including a music school and an open-air "forest-school" biodiversity research and training center, a small butterfly sanctuary, locally made coffee, a community store, a community radio station (the first in the country), and a lightemitting diode (LED) public lighting system replacing the obsolete/expensive public system. In practicing these projects of autogestion, the organization's goal has been to challenge colonialist-developmentalist hegemony and experiment with re-articulation of common senses in multiple dimensions of everyday life: from the mines to the forest; from the forest to the house; from the house to the school; from the school to the economy; from the economy to the [forest] reserve (Massol-González, Johnnidis, and Massol-Deyá 2008, 14). In what follows, we elaborate on how Casa Pueblo performs commoning as sustained by the materiality of communal territory and reframed with common senses in three domains: (1) democracy, (2) nation/community and (3) nature/forest.

\section{Re-Commoning Democracy: Performing a Common(s) Life}

The common sense about democracy is one of a liberal-representative system where elections and state-guaranteed equal rights of citizens under rule of law are the most important aspects. Casa Pueblo has been driven by the desire to perform democracy differently as "the need for establishing in the conscience

${ }^{4}$ Non-English sources translated by the authors unless otherwise stated. 
not only the notion of claiming rights, but also of putting into practice the knowledge of rights and recognition of responsibilities" (Massol-González, Johnnidis, and Massol-Deyá 2008, 8). This was evident during the 1993 "People's Forum" where Casa Pueblo, aiming to invert top-down participation, experimented with a form of democracy based on citizen-led dialogue and gave the government the opportunity to present their mining proposal and be questioned by the region's citizens, including children (Massol-González, Johnnidis, and Massol-Deyá 2008). One relevant result was to convince Adjuntas' mayor and municipal legislature to oppose the mining project.

Similarly, in 1995 Casa Pueblo organized a town mobilization where hundreds of people marched to the main mineral reservoir and planted trees under the slogan "We have already decided: No to the mines." It was a performance of democratic rights and the concept of a government for and by the people, reminiscent of the Zapatista slogan "Out with the bad government, here the people rule." Days after this mobilization the law banning open pit mining was approved. Casa Pueblo called this "the law of the people" (ley del pueblo) (Martínez-Reyes 2009), an illustration of how standard democratic procedures of public hearings and making laws could be performed and repeated differently with an awareness of our embeddedness in power relations and a desire to re-signify such relations. It shifted the focus "from having power (which automatically makes it the possession of some at the expense of others) to practicing power (which is a possibility for all)" (Velicu and Kaika 2015, 9, emphasis in original).

In this process to re-articulate democracy one can notice how a "co-management" agreement (formal legal name) has de facto become a communitypolitically controlled process. A "forest management council," composed of Casa Pueblo leaders, local residents, workers, and scientists, makes proposals about how to manage the forest. In 2016 the organization began organizing an annual assembly open to anyone who wishes to review and discuss Casa Pueblo's ongoing initiatives and contribute to improve and expand them. The decision-making approach is described by Casa Pueblo as one of horizontalism: "everyone is important, from Ramon the maintenance worker to outside collaborators" (Massol-González, quoted in Martínez-Reyes 2009). The day-to-day activities (e.g. maintenance and tours of the facilities and the forest, roasting coffee), meanwhile, are run by volunteers, mostly from the local community. The state's role is reduced to making an annual payment to the organization as stipulated in their joint agreement and to participate in Casa Pueblo's activities as guests. These practices of community forest management, coupled with the organization's economic activities (particularly its coffee and community store) have been a way to challenge the colonial dependency common sense and articulate the democratic commons sense of self-governance and citizen power with responsibility for nurturing more egalitarian and sustainable socio-ecological relations and territories 
for the common good. Thanks to this "success" Casa Pueblo receives more than 20,000 visitors annually from schools and universities, social organizations and families.

Casa Pueblo has also reframed democracy by performing a "right to resist" (cf. Armiero and D'Alisa 2012), inspiring other struggles against destructive projects. This is a reminder that, rather than isolated autonomous "enclaves," commoning needs to be coupled with broader social movements for democratic political-economic transformations (cf. Caggiano and De Rosa 2015; De Angelis 2012). The most recent of these struggles was against a proposed gas pipeline, labeled by activists as "the pipeline of death," that would have passed along the northern coast and cross from north to south through the Central Cordillera, including People's Forest. The pipeline was defeated after several years of opposition, in which Casa Pueblo played a key role, having organized a mobilization of tens of thousands of people in Adjuntas on 1 May 2010 (international workers day). On this occasion Casa Pueblo once more emphasized the sovereignty of the people:

If [then-governor] Fortuño, his government or whoever decides to impose the construction of this nefarious project, leaving no alternative to choose between death or life, I will choose life ... in my sovereign right to self-defense of the waters, the forests, the karst and the security of our people ... (in DelgadoEsquilín 2011)

In this way these performances are ultimately about a right to live - that is, to allow freer social reproduction, to sustain life on and of the earth (cf. De la Cadena 2015; Di Chiro 2008; Reid and Taylor 2010; Turner and Brownhill 2004). Following Butler $(2015,11)$, this politics embodies "a plural and performative right to appear" that "delivers a bodily demand for a more livable set of economic, social, and political conditions no longer afflicted by induced forms of precarity ... put livable life at the forefront of politics" in a context in which some human and other populations are considered dispensable. Casa Pueblo has consistently sought to prevent the inhabitability that mining or other destructive projects would create (Massol-González in Cela 2014). The counter-hegemonic potential of these performances lies also in their being "projects of life," that is, livable, democratic, ecological alternatives for all people and lives (rather than of simply conservationist or distributive character): forestation, low-scale and ecological agriculture, cultural and ecological education activities, renewable energy, small-scale and ecological tourism, etc. It is about living/performing a form of life that is not at the expense but rather in support of other (human and non-human) lives, a common(s) sense of life. Surely this is not a politics exempt of contradictions and ambiguities. What counts as life and who speaks for it can be interpreted differently and can tend towards an anthropocentrism where only (certain) human lives matter (cf. Butler 2004). Aware of these, Casa Pueblo seeks to keep open the 
horizon of who and what (human and non-humans) can be included in such politics, as we discuss in the next two subsections.

\section{From the Local Community to the Geographic Homeland}

The common sense of community associated with the neoliberal vision of commons is of a geographically conscript, small-scale, homogeneous entity with an essentialist/dualist idea of group/identity which also serves to pin down people/beings to certain roles (Velicu and Kaika 2015). In their enactment of commoning, Casa Pueblo has rearticulated this common sense through different performative practices, reworking the concrete meaning of the community at different levels (the national community, the local community, the environmentalist community).

For instance, the concept of patria, or homeland, has been at the core of Casa Pueblo's performance since the beginning. Yet their use of the term was different from that of traditional nationalists. While denouncing the colonial mine, it also challenged the sectors of the left which at the time supported mining for national benefit. Casa Pueblo's slogans "Yes to Life, No to the Mines" opened the door to a different common sense of nation which was not just about legal independence from the U.S. at any cost, nor on an abstraction of patriotic commitment of citizens acting for the benefit of the nation (liberal) state. Casa Pueblo proposed that national(ist) feelings of geographical rootedness, rather than leading to a closed ideological engagement, could serve to mobilize attachment to proliferate the continuously open and expansive community of commoning. The "nation" was a collective of peoples united by their oppressions and struggling for communal self-governance of their territories in order to have a country that is alive (Massol-Deyá 2015) - ecologically and socially. The people grounded in each territory have to do their part to defend and sustain the commons, built on people's relations with (home)land in its socio-ecological diversity, a collective defense of the Earth more broadly and deeply perceived. This is similar to the Zapatistas' idea of homeland, defined as love for "a world within many worlds" (cf. García López 2015).

This redefined "nation" was paralleled by a rearticulated "community": from "the immediacy of our local native town" into a community defined by their shared "[geographic] homeland," sharing both rights and responsibilities "in the search for a more just, harmonic and universal society" (see Massol-González et al. 2006, 25-26). In other words, Casa Pueblo's community was redefined as one of praxis, "undoing" justice by re-imagining equality (Velicu and Kaika 2015). Thus, the task for Casa Pueblo is not only to create and sustain their (local) community but to unite the many struggles of

${ }^{5}$ http://casapueblo.org/index.php/proyectos/escuela-de-musica-icbc/. 
autogestión "as brothers/sisters [hermanados] in a process aimed at transcendent action to rescue our own destiny" (Massol-González quoted in DelgadoEsquilín 2011). Casa Pueblo has practiced this common(s) sense by constantly participating in many other struggles around the country and abroad, such as the fight against the U.S. military in the Puerto Rican island of Vieques, the movement against the Keystone XL pipeline in the U.S., and most recently against the dumping of toxic ashes from a coal power plant in southern Puerto Rico. Practicing this has meant welcoming people with different ideologies, identities and ecologies. Indeed, the decision to organize the march against the pipeline in 2010 on May Day alongside labor unions powerfully reworked the common sense of the pipeline as an exclusively environmental issue, making it also about the perversity of capital accumulation strategies hidden as false solutions to the country's energy problems, and the implications for working class families. These connections are crucial to challenge the mainstream discourse that portrays the working class and environmentalists as clashing forces (cf. Barca 2014).

Casa Pueblo's re-signification of community is also evident in their proposals for the progressive expansion of the People's Forest and their assembly into a network of allies in Latin America. One concrete practice that exemplifies this is the annual "reception" that they organize for the "Julián Chivi" birds on their annual migration from the Amazon to Adjuntas. Another example is Casa Pueblo's integration into the Iberoamerican Network of Model Forests ${ }^{6}$ since 2009, which promotes more democratic and sustainable territories through multi-stakeholder civil society boards. At the beginning of 2016 Casa Pueblo hosted the Network's annual meeting and made agreements with an Ecuadorian community to develop cooperative exchange visits and with Dominican Republic and Cuba to create a "Caribbean-wide forest." With this event they sought to make visible and enact their alternative common sense that "Puerto Rico is also Latin America" (Massol-González in PRTQ 2016), a simple but radical re-articulation in Puerto Rico's colonial context which invisibilizes the country from the world. Later the same year Casa Pueblo furthered this idea with the organization of an "Encounter of Latin American women struggling in defense of the environment," with the participation of local environmental leaders from Honduras, Guatemala, Peru and Ecuador who shared their experiences of dispossessions and commoning struggles.

Finally, Casa Pueblo's "open community" bound by solidarity and an ecological conscience is manifested daily in the practices of the organization's "house" and cultural-environmental center. The name itself holds associations with the commons: a house that is the people, and of/for the people. The center opens seven days a week and receives hundreds of visitors daily.

\footnotetext{
${ }^{6}$ See http://www.bosquesmodelo.net.
} 
With doors literally wide open and a living room, founders talk with visitors and it feels like going to the home of family or close friends enjoying a cup of the organization's Madre Isla ("Mother Island") coffee - roasted and brewed by Casa Pueblo's members. This is a central part of performing a symbolic ritual to slow down, enjoy a conversation and "taste" the solidarity (as members like to say), also suggestive of their attention to "the sensible" in commoning, a crucial but often marginalized dimension of movements' performativity (cf. Velicu 2015).

In sum, while drawing on nationalist symbols/identities and territorial attachments, Casa Pueblo has sought to be an open and pluralist project, focused not on identitarian-ideological sameness but more broadly on "vibrant matter" (Bennett 2009) defending and nurturing the relational civic-ecological commons (cf. De la Cadena 2015; Reid and Taylor 2010). This "opening up" of community is arguably necessary for developing a non-violent ethics of commoning "without obedience to a normative 'telos' of definitional closure" (Butler 1999, 22; see also Butler 2004).

\section{A Forest with/for People}

Counter-hegemonic commons have been theorized as recentering the political around the co-constitutive relations among humans and non-human entities, challenging the false separation of nature and society at the heart of the capitalist project (Bresnihan 2016; De la Cadena 2015; Gibson-Graham and Miller 2015; Reid and Taylor 2010). Since its initial struggle against the mines Casa Pueblo has challenged the hegemonic common sense that the forests are either for conservation or for exploitation. Instead, the organization proposes to see the multiplicity of the forest's vitalities, both material - for example, livelihood and human survival - and non-material - such as emancipatory education, poetic/musical inspiration and spirituality. The forest becomes the territorial grounding for performing the common(s) sense that freedom and well-being cannot come without a political project that is explicitly ecological, collective and commons-based.

The naming of the People's Forest is not coincidental: Casa Pueblo performs "a forest with people," an interconnected civic and ecological commoning and re-commoning of relations for the common good of earthly beings and "matter" (water, food, land, spirituality and place-based learning), rather than for (exchange-surplus) private profit. Tree-planting activities organized during and after the anti-mining struggle have not only been a way to enact the people's sovereign rights over the territory but also to make visible the interconnectedness of ecology, society and economy. One such activity was Sembrando Esperanza (Planting/Sowing Hope) where trees were planted to emphasize their relevance for a "livable life" of freedom: ecological concerns as well as livelihoods producing wood and 
fruit that could generate sustainable, non-destructive community economies (Martínez-Reyes 2009).

In 1989 Casa Pueblo began the production and marketing of coffee from the region under the Madre Isla name. This coffee continues to provide an important source of income for the organization today. Madre Isla is partly produced in the People's Forest and partly bought from other local producers at fair prices, and is roasted and packed entirely by the organization's volunteers. Casa Pueblo also works with the farmers to help them implement biological pest controls and to shift to shade-grown coffee. This everyday performance redefines the economy as "ecological livelihood" based on working, caring for and reproducing the land for the common good and doing so in/through commons (cf. Gibson-Graham and Miller 2015; Mackenzie 2010). The advancement of an ecological and cooperative economy is also seen in Casa Pueblo's alliance with the "Model Forests" initiative through which they have promoted the integration of agriculture, tourism, forest conservation and other activities into "working landscapes." These are led by a permanent dialogue between the region's inhabitants to stimulate a "collective consciousness" towards a truly sustainable and solidary development of the territory. Their experience reminds us that alternative economies are also commoning projects (cf. Caggiano and De Rosa 2015; D'Alisa, Forno, and Maurano 2015; De Angelis 2012; Varvarousis and Kallis 2017).

A recent reforestation activity further exemplifies this performativity. When a large and intentionally set forest fire destroyed hundreds of hectares of the People's Forest, Casa Pueblo mobilized hundreds of volunteers from all over the country on short notice to plant a 1000 trees in the affected area, and took the opportunity to transform the forest to include fruit trees and bamboo wood that could be used for food, housing and economic projects. Apart from the objective of ecological restoration, the activity served to demonstrate a collective self-organized commitment to the forest and the country and to further the connection between people and ecology, engaging people directly in the management of the land (Massol-González in Irizarry Álvarez 2014). The recognition of the bodily and emotional interdependence with the forest was visible in one of the participants' explanation that he was there "to devolve to the land a little of the love that it gives us" (Massol-González in Torres and Alfonso 2014). Furthermore, Casa Pueblo took the opportunity to connect the struggle for the "rebirth" of the forest and the anti/decolonial struggle, opening the event with the musical version of a poem by Corretjer - their mentor and an icon of the socialist and pro-independence movement - and having the daughter of political prisoner Oscar Lopez Rivera (who has been in U.S. jails for more than 35 years for his independence activism) plant a tree in his honor. Thus, collective solidarity-based practices of reforesting and caring for forestlands were a means to transform subjectivities towards performing commoning selves (cf. Singh 2013). 
Performing this new common sense of a "forest with people" is mobilized in the everyday through Casa Pueblo's educational arm, the Community Biodiversity Institute, founded in 2002. The Institute organizes events of different duration in and about the forest - from short trips with one-day visitors to summer courses with university students, and, most recently, semester-long engagements within the "Forest School" project where local schools and visitors hold classes in classrooms in the forest. In these year-long activities the participants walk through different parts of the forest to learn, for instance, how the forest provides water through rivers that flow from the Cordillera Central to the capital city of San Juan.

Visitors are also offered music and theater events in the forest where, again, the common sense of popular culture is mobilized and rearticulated for an altogether different purpose than commercial-consumerist aims. This performs differently the relationships of people to the forest, making visible the invisible forest materialities and interconnections that sustain life (water, culture). Through the guided tours, camping, courses and other activities the forest becomes a live laboratory in which to directly experience such interconnections: the forest as provider of livelihoods, knowledge, tranquility, music, etc., and people as part of the ecosystem, their lives, identities, politics and economies bound up in it.

Casa Pueblo's performance turns the forest into an Agora, a forum for "relearning and discussion of the elements of nature and of life itself to be able to process the reality in a more eclectic, integrated and universal manner."7 This "relearning" (or performing) is upheld as essential to the practice of democratic rights and responsibilities to nurture the geographic/ecological homeland. As stated at the Casa Pueblo's website, "It is precisely the expansion of this collective consciousness that will allow civil society to make one of its priorities the conservation of our homeland [suelo patrio] around the integrity of our environment, culture and struggles as a nation." Ecology becomes the center of a process in which "the community becomes a part of the forest” (Massol-González, Johnnidis, and MassolDeyá 2008).

In sum, these everyday practices of visiting, caring for and learning in the forest are much more than the typical conservationist dreams of "passively consuming" nature for spiritual redemption, or the technocratic model of scientific "ecological restoration." They reconfigure the idea of a "pristine" nature, breaking with its colonial past and showing that it is not separate from social/cultural processes. As ecofeminists and commoning scholars would suggest, nature for Casa Pueblo is an integral part of culture/ economy/politics and the process of building a "community subjectivity" ${ }^{7}$ http://bosqueescuela.org/index.php?option=com_content\&view=article\&id=113\&ltemid=292. Emphasis
added. 
(cf. Mackenzie 2010) and a transformative political project (radically democratic, anti-colonialist, emancipatory).

\section{The Performance of Livable Worlds in Counter-Hegemonic Commons}

Casa Pueblo - a project of autogestion seeking to further individual and collective freedom, justice and ecological sustainability - has provided an entry point to reflection on a view of (counter-)hegemony based on the concepts of common senses and performativity. The movement illustrated how existing common senses regarding democracy, nation/community and forests/nature can be mobilized and rearticulated through performative commoning grounded in the material basis of their geographic homeland.

In using Casa Pueblo as illustration we do not mean to make a Manichean distinction between "good local" commons and "bad capitalist" processes. We want to stress the ways in which performing commons (i.e. commoning) creates vitalities for counter-hegemonic re-articulation of common senses that challenge neoliberal hegemony in particular contexts. What we see as performance of counter-hegemony (the articulation of new common(s) senses) is a way to repoliticize the organization of community life, its economy and ecology. These apparently localized and isolated experiments may contribute to a broader questioning of capitalism as a system where decisions are rooted in exchange value, private ownership and self-interest.

We recognize that there is a long road from particular commoning processes to a broader radical transformation that could replace capitalism. Performative re-articulations are full of "surprises, disturbances and disruptions" which challenge us to think differently - beyond foundations - about reality (Velicu and Kaika 2015, 10). Gramsci was emphatic that the process of building a counter-hegemony was "long, full of contradictions, advances and retreats" (Gramsci 1971, 334). All movements and commoning processes have their contradictions and ambivalences (Chatterton, Featherstone, and Routledge 2013; De Angelis 2007, 2012; St. Martin 2005), and Casa Pueblo is not an exception. For instance, despite its appeals to horizontalism and community, it is also true that the Massol-Deyá family have been prominent leaders of the movement. Some have also questioned the organization for a perceived tendency of excessive prominence (protagonismo) in certain struggles while not strongly supporting others. One may also be wary of their recent proposal to measure the economic value of the water-provisioning services of the forest. Finally, despite Casa Pueblo's struggles, a neoliberal colonialist regime continues in full force in Puerto Rico. Facing a $\$ 70+$ billion debt, the country is now administered by a U.S. fiscal control board that is mandating a new wave of drastic austerity measures to pay off bondholders. Casa Pueblo has vowed to struggle against any threats to public lands (which 
may be sold to pay off debt), yet so far the organization has not been visible in the emerging anti-austerity movement.

While recognizing limitations and contradictions of commoning one must keep in mind that the left's tendency for critique and apparent desire for "radical perfection" - a dismissal of the transformative potential of alternatives - often ends up being debilitating, even paralyzing, and serves to perpetuate the hegemony of capital and the idea that there are no alternatives (Gibson-Graham 2006). In their long history Casa Pueblo have remained committed to an experimental project of demonstrating (performing) alternative present and future worlds based on the defense and regeneration of livable (human and non-human) lives. Their project is one of constant "evolution and re(e)volution," with dynamism and without "fear afraid to face errors or contradictions" (Massol-González in Ruiz Marrero 2014) while being aware that, as their mentor Corretjer once said, life is a "never-ending struggle for freedom."

\section{Conclusions}

In this paper we have argued that a political ecology of the commons requires attention to understanding hegemony and its performative (re)articulations of common(s) senses. We build on a revised definition of hegemony based on the idea of re-articulation of common senses (D'Alisa and Kallis 2016) through everyday performances (Velicu and Kaika 2015). Paraphrasing Butler we can say that performativity is fundamental to recited common senses in a way that their reordering shifts their meaning and can undo and debunk actual current hegemony. Bridging Butler and Gramsci, we maintain, helps understand counter-hegemony not as a final state but as a constant process of struggle around a certain articulation of common(s) senses. We maintain this can be used not only as a theoretical tool but also a methodological approach to unveil why commoning and its performative re-articulations of common senses has counter-hegemonic potential. From this perspective counter-hegemonic commons are not found in a pre-defined ideological program but in performing differently in a constantly evolving process of openness, experimentation and solidarity (cf. Chatterton, Featherstone, and Routledge 2013). These everyday performances are precisely what prefigures and gives concrete meaning to the alternative commons senses that counter-hegemony requires.

\section{Acknowledgements}

The authors wish to thank two anonymous reviewers and CNS editor Salvatore Engeldi-Mauro for their extremely helpful critical comments, as well as all of the members of the European Network of Political Ecology (ENTITLE) collective who contributed 
to and inspired us in writing this paper in different but crucial ways. They also thank Adi Forkasiewicz from CNS for his very careful copy-editing.

\section{Disclosure Statement}

No potential conflict of interest was reported by the authors.

\section{Funding}

The work on this article was made possible with generous funding for all three authors from the European Network of Political Ecology (ENTITLE) project, financed by the Marie Curie Initial Training Network Programme, Seventh Framework Programme [grant no. PITN-GA-2011-289374-ENTITLE]; and additional funding for I. Velicu from the Portuguese Foundation for Science and Technology (FCT) Post-Doctoral Grants in the Centre for Social Studies at University of Coimbra [grant no. SFRHBPD-94680-2013].

\section{References}

Anazagasty-Rodríguez, José. 2015. "Por Razones Prácticas y Éticas.” 80 grados, December 18. http://www.80grados.net/por-razones-practicas-y-eticas/.

Armiero, Marco, and Giacomo D’Alisa. 2012. "Rights of Resistance: The Garbage Struggles for Environmental Justice in Campania, Italy." Capitalism Nature Socialism 23 (4): 52-68.

Barca, Stefania. 2014. "Laboring the Earth: Transnational Reflections on the Environmental History of Work." Environmental History 19 (1): 3-27.

Bennett, Jane. 2009. Vibrant Matter: A Political Ecology of Things. Durham, NC: Duke University Press.

Bollier, David, and Silka Helfrich. 2015. Patterns of Commoning. Amherst, MA: Levellers Press.

Brand, Ulrich, and Christoph Görg. 2013. "Regimes in Global Environmental Governance and the Internationalization of the State." International Journal of Social Science Studies 1 (1): 110-122.

Bresnihan, Patrick. 2016. "The More than Human Commons: From Commons to Commoning." In Space, Power and the Commons, edited by Samuel Kirwan, Leila Dawney, and Julian Brigstocke, 93-112. New York: Routledge.

Butler, Judith. 1997. "Further Reflections on Conversations of Our Time." Diatrics 27 (1): 13-15.

Butler, Judith. 1999. Gender Trouble: Feminism and the Subversion of Identity. New York: Routledge.

Butler, Judith. 2000. "Restaging the Universal: Hegemony and the Limits of Formalism." In Contingency, Hegemony, Universality. Contemporary Dialogues on the Left, edited by Judith Butler, Ernesto Laclau, and Slavok Žižek, 11-43. London: Verso.

Butler, Judith. 2004. Undoing Gender. London: Routledge.

Butler, Judith. 2015. Notes Toward a Performative Theory of Assembly. Cambridge, MA: Harvard University Press.

Caffentzis, George, and Silvia Federici. 2014. "Commons Against and Beyond Capitalism.” Community Development Journal 49 (S1): i92-i105. 
Caggiano, Monica, and Salvatore P. De Rosa. 2015. "Social Economy as Antidote to Criminal Economy: How Social Cooperation is Reclaiming Commons in the Context of Campania's Environmental Conflicts." Partecipazione e Conflitto 8 (2): 530-554.

Cela, María C. 2014. “¿Cómo Sería Puerto Rico en el 2020?” El Nuevo Día, September 8. Chatterton, Paul, David Featherstone, and Paul Routledge. 2013. "Articulating Climate Justice in Copenhagen: Antagonism, the Commons, and Solidarity." Antipode 45 (3): 602-620.

Colón-Rivera, Jorge, Félix Córdova-Iturregui, and José Córdova-Iturregui. 2014. El Proyecto de Explotación Minera en Puerto Rico (1962-1968): Nacimiento de la Conciencia Ambiental Moderna. San Juan: Ediciones Huracán.

Compost, Claudia, and Mina L. Navarro. 2014. "Claves de Lectura para Comprender el Despojo y las Luchas por los Bienes Comunes Naturales en América Latina.” In Territorios en Disputa, edited by Claudia Compost, and Mina L. Navarro, 33-75. Mexico, DF: Bajo Tierra Ediciones.

Concepción, Carmen M. 1995. "The Origins of Modern Environmental Activism in Puerto Rico in the 1960s." International Journal of Urban and Regional Research 19 (1): 112-128.

D’Alisa, Giacomo. 2013. “Bienes Comunes: Las Estructuras que Conectan.” Ecología Política 45: 30-41.

D’Alisa, Giacomo, Francesca Forno, and Simon Maurano. 2015. “Grasroots (Economic) Activism in Times of Crisis: Mapping the Redundancy of Collective Actions." Partecipazione e Conflitto 8 (2): 328-342.

D’Alisa, Giacomo, and Giorgos Kallis. 2016. "A Political Ecology of Maladaptation: Insights from a Gramscian Theory of the State." Global Environmental Change 38: 230-242.

De Angelis, Massimo. 2001. "Marx and Primitive Accumulation: The Continuous Character of Capital's 'Enclosures'." The Commoner 2 (1): 1-22. http://www. thecommoner.org/.

De Angelis, Massimo. 2007. The Beginning of History: Value Struggles and Global Capital. London: Pluto Press.

De Angelis, Massimo. 2012. "Crises, Movements and Commons." Borderlands 11 (2): $1-22$.

De Angelis, Massimo. 2013. “Does Capital Need a Commons Fix?” Ephemera 13 (3): 603-615.

De la Cadena, Marsiol. 2015. “Uncommoning Nature.” E-flux, 56th Biennale, August 22. http://supercommunity.e-flux.com/authors/marisol-de-la-cadena/.

Delgado-Esquilín, Gerardo. 2011. “Consideran al Gasoducto Vía Verde el Próximo Vieques." Mi Puerto Rico Verde, May 2. http://www.miprv.com/sera-elgasoductovia-verde-el-proximo-vieques/.

Di Chiro, Giovanna. 2008. "Living Environmentalisms: Coalition Politics, Social Reproduction, and Environmental Justice.” Environmental Politics 17 (2): 276-298.

Ekers, Michael. 2013. "Gramsci and the Erotics of Labor: More Notes on "The Sexual Question'.” In Gramsci: Space, Nature, Politics, edited by Michael Ekers, Gillian Hart, Stefan Kipfer, and Alex Loftus, 217-238. Malden, MA: Wiley-Blackwell.

Ekers, Michael, Gillian Hart, Stefan Kipfer, and Alex Loftus, eds. 2013. Gramsci: Space, Nature, Politics. Malden, MA: Wiley-Blackwell.

Federici, Silvia. 2012. Revolution at Point Zero: Housework, Reproduction, and Feminist Struggle. Oakland, CA: PM Press. 
García López, Gustavo A. 2015. "Recuperar los Comunes Para un País Vivo: Perspectivas Desde la Lucha Contra el Despojo y por la Autogestión Comunitaria en Casa Pueblo, Puerto Rico.” Ecología Política 49: 51-60.

Gibson-Graham, J. K. 2006. A Postcapitalist Politics. Minneapolis: University of Minnesota Press.

Gibson-Graham, J. K., and Ethan Miller. 2015. "Economy as Ecological Livelihood." In Manifesto for Living in the Anthropocene, edited by Katherine Gibson, Deborah B. Rose, and Ruth Fincher, chapter 2. Brooklyn, NY: Punctum Books.

Goldman, Michael. 1993. "Tragedy of the Commons or the Commoners' Tragedy: The State and Ecological Crisis in India." Capitalism Nature Socialism 4 (4): 49-68.

Gramsci, Antonio. 1971. Selections from the Prison Notebooks. Edited and Translated by Quintin Hoare and Geoffrey Nowell Smith. London: Lawrence and Wishart.

Harvey, David. 2003. The New Imperialism. Oxford: Oxford University Press.

Heynen, Nick, and Paul Robbins. 2005. "The Neoliberalization of Nature: Governance, Privatization, Enclosure and Valuation." Capitalism Nature Socialism 16 (1): 5-8.

Hopgood-Dávila, Eugenio. 2015. “35 Años de Ciencia, Cultura y Comunidad.” Puerto Rico Te Quiero, April 19. http://puertoricotequiero.com/35-anos-de-cienciacultura-y-comunidad/.

Irizarry Álvarez, Femi. 2014. "Bosque Modelo Resurge de las Cenizas Como el Ave Fénix.” Primera Hora, July 9.

Johnston, Josée. 2003. "Who Cares About the Commons?" Capitalism Nature Socialism 14 (4): 1-41.

Karriem, Abdurazack. 2013. "Space, Ecology, and Politics in the Praxis of the Brazilian Landless Movement." In Gramsci: Space, Nature, Politics, edited by Michael Ekers, Gillian Hart, Stefan Kipfer, and Alex Loftus, 142-160. Malden, MA: WileyBlackwell.

Kreps, David, ed. 2015. Gramsci and Foucault: A Reassessment. Farnham, Surrey: Ashgate.

Linebaugh, Peter. 2008. The Magna Carta Manifesto. Berkeley: University of California Press.

Mackenzie, Fiona Douglas. 2010. "A Common Claim: Community Land Ownership in the Outer Hebrides, Scotland." International Journal of the Commons 4 (1): 319344.

Martínez-Reyes, José. 2009. “Comunidad, Estado y Naturaleza: La Ecología Política del Manejo Colaborativo de Bosques.” Revista de Ciencias Sociales 20: 128-155.

Massol-Deyá, Arturo. 2015. “Agenda para un País Vivo.” El Nuevo Día, August 2.

Massol-González, Alexis, Edgardo González, Arturo Massol-Deyá, and Tine Geoghegan. 2006. Bosque del Pueblo, Puerto Rico: How a Fight to Stop a Mine Ended Up Changing Forest Policy from the Bottom Up. London: International Institute for Environment and Development.

Massol-González, Alexis, Avril Andromache Johnnidis, and Arturo Massol-Deyá. 2008. The Evolution of Casa Pueblo, Puerto Rico: From Mining Opposition to Community Revolution. London: International Institute for Environment and Development.

McCarthy, James. 2005. "Commons as Counter-Hegemonic Projects." Capitalism Nature Socialism 16 (1): 9-24.

Nightingale, Andrea. 2013. "Fishing for Nature: The Politics of Subjectivity and Emotion in Scottish Inshore Fisheries Management." Environment and Planning A 45: 2362-2378. 
Puerto Rico Te Quiero (PRTQ). 2016. "Casa Pueblo establece acuerdos con Cuba, Dominicana y Ecuador.” March 9. http://puertoricotequiero.com/casa-puebloestablece-acuerdos-con-cuba-dominicana-y-ecuador/.

Reid, Betsy, and Harry Taylor. 2010. Recovering the Commons: Democracy, Place and Global Justice. Chicago: University of Illinois Press.

Ruiz Marrero, Carmelo. 2014. "La lucha ecológica venció al cobre en Puerto Rico.” IPS Noticias, October 14. http://www.ipsnoticias.net/2014/10/la-lucha-ecologicavencio-al-cobre-en-puerto-rico/.

Sevilla-Buitrago, Álvaro. 2017. "Gramsci and Foucault in Central Park: Environmental Hegemonies, Pedagogical Spaces and Integral State Formations." Environment and Planning D 35 (7): 165-183.

Singh, Neera M. 2013. "The Affective Labor of Growing Forests and the Becoming of Environmental Subjects: Rethinking Environmentality in Odisha, India." Geoforum 47: 189-198.

St. Martin, Kevin. 2005. "Disrupting Enclosure in New England Fisheries.” Capitalism Nature Socialism 16 (1): 63-80.

Tola, Miriam. 2015. "Commoning With/in the Earth: Hardt, Negri and Feminist Natures." Theory and Event 18 (4). https://muse.jhu.edu/article/595841.

Torres, Sandra, and Omar Alfonso. 2014. "Siembra esperanza el Bosque del Pueblo." La Perla del Sur, April 30. http://www.periodicolaperla.com/siembran-laesperanza-en-el-renovado-bosque-del-pueblo/.

Turner, Terisa E., and Leigh S. Brownhill. 2004. "We Want Our Land Back: Gendered Class Analysis, the Second Contradiction of Capitalism and Social Movement Theory." Capitalism Nature Socialism 15 (4): 21-40.

Turner, Terisa E., and Leigh S. Brownhill. 2010. "Ecofeminism and the Global Movement of Social Movements." Capitalism Nature Socialism 21 (2): 102-106.

Varvarousis, Aggelos, Giorgos Kallis, et al. 2017. "Commoning Against the Crisis." In Another Economy is Possible: Culture and Economy in a Time of Crisis, edited by Manuel Castells, 128-159. Cambridge: Polity Press.

Velicu, Irina. 2015. "Demonizing the Sensible and the 'Revolution of our Generation' in Rosia Montana." Globalizations 12 (6): 1-13.

Velicu, Irina, and Maria Kaika. Forthcoming. "Undoing Environmental Justice: ReImagining Equality in the Rosia Montana Anti-mining Movement." Geoforum. doi:10.1016/j.geoforum.2015.10.012. 